\title{
PERAN MEDIA SOSIAL DALAM DEMOKRASI MASA KINI
}

\author{
Munazahatul Kholisoh ${ }^{1}$, Tri Nurkhaeni ${ }^{2}$, Putri Surya Ningrum ${ }^{3}$, Intan Fitriani ${ }^{4}$ \\ Program Studi Ilmu Administrasi Negara, FISIP, Universitas Tidar Magelang \\ Jl. Kapten Suparman No. 39, Potrobangsan, Magelang Utara 56116 \\ E-mail:trienurulaeni7@gmail.com
}

\begin{abstract}
Technological developments have penetrated human life. One of the social media that originally only functioned as a means of self-existence, is now changing to influence the political climate of a country. In the democation of the media including the fourth pillar because it is considered more neutral and independent than the elements of state power. With the existence of this social media, the community is increasingly appreciative and active regarding actual issues that occur, of course this can increase public participation related to public issues. This research illustrates that democracy in the digital era can facilitate the process of democracy and social media can be used as a public space to aspire to democracy that is implemented according to the wishes of the people or still needs to be improved, but we as users must be able to choose information so that they do not easily believe in the news hoax. This study uses a survey method with non-physical student subjects at the Tidar University.
\end{abstract}

Keywords : social media, democracy, digital era

Abstrak: Perkembangan teknologi telah merambah kehidupan umat manusia. Media sosial salah satunya yang semula hanya berfungsi sebagai alat eksistensi diri, kini merubah untuk mempengaruhi iklim politik suatu negara. Dalam demokasi media termasuk pilar keempat karena dianggap lebih netral dan bebeas dari unsur kekuasaan negara. Dengan adanya media sosial ini masyarakat semakin apresiatif dan aktif terkait isu-isu aktual yang terjadi, tentu hal ini bisa meningkatkan partisipasi masyarakat terkait dengan isu-isu publik. Penelitian ini menggambarkan demokrasi pada era digital dapat mempermudah terkait proses demokrasi dan juga media sosial bisa dijadikan ruang publik untuk beraspirasi terkait demokrasi yang diterapkan sudah sesuai keinginan rakyat atau masih perlu diperbaiki, tetapi kita sebagai pengguna juga harus mampu memilih informasi agar tidak mudah percaya pada berita hoax. Penelitian ini menggunakan pendekatan kualitatif dengan metode pemgumpulan data survey dan wawancara dengan subjek mahasiswa non-FISIP di Universitas Tidar.

Kata kunci : media sosial, demokrasi, era digital 


\section{A. PENDAHULUAN}

Seiring dengan bertambahnya zaman, ilmu pengetahuan dan teknologi semakin mengalami perkembangan yang pesat. Salah satu wujud perkembangan teknologi tersebut, ada pada bidang teknologi informasi dan komunikasi. Saat ini, teknologi informasi dan komunikasi telah terbukti sebagai sarana komunikasi dan sumber informasi yang sangat handal. Teknologi tersebut telah dimanfaatkan hampir di setiap aspek kehidupan manusia, baik dari pekerjaan, pendidikan, maupun dalam pemerintahan. Sehingga, kini media komunikasi semakin menduduki peran yang penting dalam aktivitas yang dilakukan manusia. Media komunikasi telah menjadi salah satu kebutuhan utama bagi setiap orang. Hal ini seiring dengan ditemukannya perangkat-perangkat media yang berbasis internet, seperti media sosial (instagram, facebook, dan sebagainya). Sehingga berbagai jenis informasi menjadi mudah ditemukan di belahan dunia dengan mengakses media melalui jaringan internet.

Media sosial adalah sebuah media online, dimana penggunanya (user) melalui aplikasi berbasis internet. Dengan hadirnya media tersebut, menunjukan adanya pergeseran arah penggunaan media komunikasi, yang semula bersifat klasik (media elektronik dan cetak) mengalami perubahan ke media baru (new media) berbasis internet. Media sosial menjadi saluran akses informasi dalam berbagai bidang, yaitu pendidikan, budaya, sosial, ekonomi, hukum, juga politik. Misalnya di yaitu digunakan di dalam kampanye pemilu untuk mensosialisasi visi misi dan program kerja suatu kandidat atau bahkan dalam Pemilu 2019 kemaren, gencar-gencarnya media sosial dijadikan ajang untuk mempromosikan pasangan calon presiden maupun calon-calon legislator. Media sosial sebagai strategi komunikasi politik merupakan alternatif baru dan menjadi fenomena yang hangat hingga kini. Seperti yang dikutip oleh Charta Politika, menyebutkan bahwa informasi di media sosial berpengaruh terhadap responden dalam menentukan pilihannya saat Pemilihan Umum 2019 mendatang. Dari survei itu, 24,4\% responden mengatakan media sosial sangat berpengaruh terhadap pilihan mereka serta 37,8\% mengatakan cukup berpengaruh. Untuk pertumbuhan pengguna media sosial, Indonesia menjadi negara ketiga terbesar dengan tingkat pertumbuhan mencapai $23 \%$ atau 24 juta pengguna dalam satu tahun terakhir. Fakta dengan meningkatnya angka pengguna media sosial ini, pada akhirnya telah membawa persaingan baru bagi partai politik dan kandidat dalam Pemilu 2019.

Andrew Chadwick (2006) menyebutkan ada tiga poin bagaimana penggunaan internet (dalam hal media sosial) dapat mempengaruhi lanskap partai politik. Pertama, media sosial akan 
meningkatkan kompetisi partai. Dalam banyak kasus, partai-partai kecil yang memiliki sumber daya terbatas, tidak memiliki pengaruh, khususnya dalam Pemilihan Umum. Namun dengan internet sebagai media yang murah dan juga lebih mudah diakses daripada teknologi komunikasi lainnya, mereka dapat bersaing dengan partai-partai besar yang memiliki sumber daya lebih kuat. Media sosial memungkinkan partai politik kecil untuk menjangkau pendukung potensial serupa dengan partai besar. Kedua, media sosial dapat meningkatkan interaksi masyarakat dengan partai politik maupun kandidat. Masyarakat memiliki akses lebih untuk menyalurkan aspirasi kepada partai politik maupun kandidat yang di dukungnya. Pada saat yang sama, partai politik dan kandidat dapat mengkoordinasikan pendukung mereka dengan lebih mudah dan cepat untuk memobilisasi mereka misalnya pada saat kampanye. Kemudian yang ketiga, sebagai adaptasi kelembagaan. Arti adaptasi kelembagaan yaitu adanya pergeseran bentuk aktifitas politik offline ke online. Partai politik maupun kandidat dapat memanfaatkan media sosial dengan kampanye yang sama seperti dalam politik offline. Melalui media sosial partai politik maupun kandidat dapat membuat strategi komunikasi lebih efektif.

Varian media sosial yang tengah berkembang dan banyak diminati orang adalah Facebook, Twitter, Whatsapp, Youtube, dan sebagainya. Media sosial sebagai sarana komunikasi memiliki peran membawa penggunanya untuk berpartisipasi secara aktif dengan memberi kontribusi dan feedback secara terbuka, baik untuk membagi maupun memberi respon secara online dalam waktu yang tepat.

Pada tahun 2018, Komisi Pemilihan Umum (KPU) menambah metode kampanye pemilu 2019, yaitu kampanye menggunakan media sosial. Ketentuan tersbeut diatur dalam Peraturan KPU (PKPU) Nomor 20 Tahun 2018 tentang Pemilihan Umum, yang isinya "Diperkenankan menggunakan media sosial sebagai metode kampanye, karena kita menyadari bahwa zaman sudah berubah, pengguna media sosial juga semakin besar". Hal ini disampaikan oleh komisioner KPU, Wahyu Setiawan. Namun jika akun-akun tersebut kontennya tidak sesuai dengan ketentuan yang berlaku, KPU Bawaslu akan menindaklanjuti terkait hal tersebut. Pelanggar juga berpotensi untuk dikenai sanksi Undang-undang Nomor 14 Tahun 2008 tentang Keterbukaan Informasi Publik.

Dari keterlibatan media sosial dalam Pemilu tersebut, terlihat bahwa media sosial juga berperan dalam pelaksanaan demokrasi di Indonesia. Selain dalam Pemilu, apresiasi masyarakat dalam media sosial juga memberi perkembangan dalam pelaksanaan demokrasi. Orang-orang 
awam semakin terbuka akan kinerja pemerintah dan mampu menyampaikan pendapatnya secara terbuka melalui media sosial yang semakin mudah diakses oleh seluruh kalangan masyarakat. Aspirasi masyarakat dalam demokrasi itu sangat penting, sebab pada demokrasi masyarakat memiliki kekuasaan tertinggi dalam pemeritahan. Sehingga penting adanya keterlibatan masyarakat dalam berjalannya pemerintahan. Untuk itu, lembaga-lembaga pemerintah semakin gencar menggunakan sosial media untuk menjalin komunikasi dengan masyarakat. Hal ini tentunya berdampak baik bagi perkembangan negara ini. Akan tetapi, ada beberapa hal yang perlu diwaspadai berkaitan seiring dengan banyaknya aliran informasi yang diterima. Fenomena hoax telah mencemari atau menebar racun dalam pelaksanaan demokrasi saat ini. Filsuf Jerman, Jurgen Habermas, percaya bahwa masyarakat perlu menerapkan apa yang ia sebut sebagai demokrasi deliberatif, yaitu kesempatan kepada banyak pihak untuk menyampaikan pendapat mereka, yang paling berbeda sekalipun, dan kemudian membiarkan masyarakat mengambil keputusan atas informasi yang beragam tersebut.

Hoax di sini bukanlah merupakan bagian dari demokrasi karena jika diteropong lewat pendekatan kebebasan memperoleh informasi (freedom of information), masyarakat perlu memiliki informasi yang lengkap dan terbuka untuk mengambil keputusan dalam pelbagai aspek kehidupannya. Hoax ini racun bagi suatu kebebasan memperoleh informasi, sementara kebebasan memperoleh informasi adalah oksigen bagi demokrasi. Dampak negatif dari penggunaan media sosial juga akan merusak prinsip-prinsip yang ada dalam demokrasi Pancasila. Meskipun begitu, peran media tetap penting bagi kelangsungan demokrasi di Indonesia.

Kelompok usia produktif merupakan pengguna internet terbanyak di Indonesia. Menurut survei Asosiasi Penyelenggara Jasa Internet Indonesia (APJII) tahun 2017, hampir separuh dari total pengguna internet di Indonesia merupakan masyarakat dalam kelompok usia 19-34 tahun $(49,52 \%)$. Dan mahasiswa termasuk dalam kelompok usia produktif tersebut. Sebagai pengguna terbanyak, mahasiswa pastinya menggunakan internet tidak terlepas dengan penggunaan media sosial. Selain pada usia dewasa, mahasiswa juga termasuk dalam kaum akademisi. Sehingga harusnya memiliki cara pandang yang berbeda sebelum melakukan sesuatu atau menghadapi suatu masalah, salah satunya yaitu dalam penggunaan media sosial di kalangan mahasiswa. Dan di awal tahun 2019 ini, hampir semua berita pada media sosial berkaitan dengan Pemilu dan pemerintahan di Indonesia. Maka, penelitian ini dilakukan untuk mengetahui peran media sosial 
kini dalam demokrasi di Indonesia melalui sudut pandang mahasiswa sebagai kaum akademisi dan agent of change, serta pandangan tentang penggunaan media sosial berkaitan dengan prinsip-prinsip dalam demokrasi Indonesia.

\section{B. KAJIAN TEORI}

\section{1) Teknologi Informasi dan Komunikasi}

Teknologi Informasi dan Komunikasi (TIK) merupakan suatu program, untuk alat bantu, manipulasi dan menyampaikan informasi. TIK adalah payung besar terminologi yang mencakup seluruh peralatan teknis untuk memproses dan menyampaikan informasi. Jika ditinjau dari asal sebuah kata teknologi. Kata teknologi berasal dari bahasa Yunani, technologia atau techne yang mempunyai arti keahlian dan logia yang berarti pengetahuan. Dalam pengertian yang sempit, teknologi merupakan sesuatu yang mengacu pada objek benda yang dipergunakan untuk kemudahan aktivitas manusia, seperti mesin, perkakas atau perangkat keras.

Teknologi Informasi dan Komunikasi (TIK) mencakup dua aspek, yaitu Teknologi Informasi dan Teknologi Komunikasi.

a. Teknologi Informasi adalah meliputi segala hal yang berkaitan dengan proses, penggunaan sebagai alat bantu, manipulasi, dan pengelolaan informasi

b. Teknologi Komunikasi adalah segala hal yang berkaitan dengan penggunaan alat bantu untuk memproses dan mentransfer data dari perangkat yang satu ke lainnya.

Teknologi Informasi dan Komunikasi suatu padanan yang tidak terpisahkan yang mengandung pengertian luas tentang segala kegiatan yang terkait dengan memproses, manipulasi, pengelolaan, dan transfer/pemindahan informasi antar media. Menurut Susanto, TIK adalah sebuah media atau alat bantu yang digunakan untuk transfer data baik itu untuk memperoleh suatu data/informasi maupun memberikan informasi kepada orang lain serta dapat digunakan untuk alat berkomunikasi baik satu arah ataupun dua arah. Sedangkan menurut Anatta Sannai, TIK adalah sebuah media atau alat bantu dalam memperoleh pengetahuan antara seseorang kepada orang lain.

Di masa lalu proses penyebarluasan informasi kepada khalayak luas dilakukan secara tradisional atau menggunakan teknologi tradisional maka di era informasi dan digital seperti sekarang proses penyebarluasan informasi dilakukan melalui teknologi baru yang jauh lebih canggih. Informasi pun dapat dikirimkan dalam berbagai macam bentuk seperti teks atau gambar 
dan melalui berbagai peralatan teknologi informasi dan komunikasi seperti telepon pintar, televisi, dan media komunikasi modernlainnya.

Perkembangan teknologi komunikasi dan informasi yang sangat cepat ini tentunya memberikan manfaat yang besar bagi kehidupan manusia. Berbagai bidang kehidupan manusia kini mulai menerapkan berbagai perangkat berteknologi baru guna memudahkan komunikasi dan pekerjaan. Adapun manfaat dari perkembangan teknologi komunikasi dan informasi bagi manusia adalah sebagai berikut :

- Berkomunikasi menjadi lebih mudah dan cepat

- Memudahkan akses informasi

- Mempersingkat waktu dan memangkas biaya

- Proses perdagangan dilakukan secara elektronik

- Membuat proses komunikasi pembelajaran menjadi semakin menarik

- Membantu proses komunikasi pemerintahan

- Komunikasi tanpa batas

\section{2) Media sosial}

Definisi dari media sosial yang dikemukakan oleh mandibergh berpendapat bahwa "media sosial adalah media yang mewadahi kerjasama di antara pengguna yang menghasilkan konten (user generated content)". Sementara itu, Boyd menjelaskan bahwa Media sosial sebagai kumpulan perangkat lunak yang memungkinkan individu maupun komunitas untuk berkumpul, berbagi, berkomunikasi, dan dalam kasus tertentu saling berkolaborasi.

Dari definisi tersebut, dapat disimpulkan bahwa media sosial adalah sarana yang merupakan medium berbasis teknologi internet (media online) yang memungkinkan seseorang dapat berinteraksi sosial, berkomunikasi dan bekerjasama serta berbagi informasi dengan orang lain. Selain itu, pengguna dengan mudah ikut berpartisipasi di dalamnya. Ardianto dalam buku Komunikasi 2.0 mengungkapkan, bahwa media sosial online disebut jejaring sosial online bukan media massa online, karena media sosial memiliki kekuatan sosial yang sangat mempengaruhi opini publik yang berkembang di masyarakat. Penggalangan dukungan atau gerakan massa bisa terbentuk karena kekuatan media online karena apa yang ada di dalam media sosial, terbukti mampu membentuk opini, sikap dan perilaku publik atau masyarakat. 
Dalam hal ini ada beberapa media sosial yang populer digunakan seperti, Facebook, Twitter, Instagram, Line, Whatsapp dan lain-lain. Menurut Sulianta, Feri (2015) karakterististik yang dijumpai pada media sosial yaitu

a. Transparansi, adalah keterbukaan informasi karena konten media sosial ditunjukkan untuk konsumsi publik untuk sekelompok orang

b. Dialog dan Komunikasi, ketika ada sebuah komunikasi maka akan terjalin hubungan dan komunikasi interaktif menggunakan ragam fitur. Misalnya media sosial seperti facebook, para penggunanya bisa saling berkomunikasi lewat chat inbox maupun saling memberi komentar pada foto yang terpasang di akun facebook yang muncul di timeline penggunanya.

c. Jejaring Relasi, hubungan antara pengguna layaknya jaring - jaring yang terhubung satu sama lain dan semakin kompleks seraya mereka menjalin komunikasi dan terus membangun pertemanan. Komunitas jejaring sosial memiliki peranan kuat yang akan memengaruhi audiensinya.

d. Multi Opini, setiap orang yang menggunakan media sosial dengan mudahnya berargumen dan mengutarakan pendapatnya misalnya dalam instagram. Seseorang yang menggunakan instagram dapat memberi komentar pada foto yang diupload oleh teman sesama instagram.

Sedangkan jenis-jenis yang dimiliki sosial media, yaitu :

- Proyek Kolaborasi

Website mengijinkan usernya untuk dapat mengubah, menambah, ataupun me-remove konten konten yang ada di website. Contohnya : Wikipedia.

- $\mathrm{B} \log$

User lebih bebas dalam mengekspresikan sesuatu di blog ini seperti curhat ataupun mengkritik kebijakan pemerintah. Contoh : wordpres dan blogspot.

- Konten

Para user dari pengguna website ini saling meng-share konten - konten media, baik seperti video, e-book, gambar, dan lain - lain. Contoh : Youtube.

- Situs jejaring sosial/ microblog

Aplikasi yang mengizinkan user untuk dapat terhubung dengan cara membuat informasi pribadi sehingga dapat terhubung dengan orang lain. Informasi pribadi itu seperti foto-foto, status, dan sebagainya. Contoh : Facebook, WhatsApp, Instagram, dan lain-lain.

- Virtual game world 
Dunia virtual, dimana mengreplikasikan lingkungan 3D, dimana user bisa muncul dalam bentuk avatar - avatar yang diinginkan serta berinteraksi dengan orang lain selayaknya di dunia nyata. Contoh : game online.

- Virtual social world

Dunia virtual yang dimana penggunanya merasa hidup di dunia virtual, sama seperti virtual game world, berinteraksi dengan yang lain. Namun, Virtual Social World lebih bebas, dan lebih ke arah kehidupan. Contoh : second life.

\section{3) Demokrasi}

Demokrasi berasal dari kata "demokratia" yang merupakan salah satu kata dari bahasa Yunani. Demokrasi sendiri memiliki arti suatu kekuasaan rakyat. Adapun secara umum, demokrasi terbagi menjadi dua kata, pertama adalah kata "demos" yang maknanya adalah rakyat. Dan kedua adalah "kratos" yang maknanya adalah kekuatan atau kekuasaan.Demokrasi itu mencakup suatu keadaan ekonomi, sosial dan juga budaya yang di dalamnya berlangsung suatu praktik kebebasan dalam bidang politik entah itu secara bebas atau secara setara.

Demokrasi berdasarkan pendapat Abraham Lincoln merupakan sebuah sistem pemerintahan dimana itu dibentuk dari rakyat, oleh rakyat dan juga untuk rakyat itu sendiri.Adapun pengertian dari demokrasi sendiri secara umum adalah sebuah format pemerintahan dimana tiap-tiap warga negara mempunyai hak yang setara dan juga seimbang mengenai penentuan dan juga pemilihan suatu keputusan yang nantinya akan memunculkan dampak di dalam kehidupan rakyat atau warga negara. Pengertian dari demokrasi sendiri juga bisa diartikan sebagai sebuah bentuk kekuasaan tertinggi yang terdapat di tangan rakyat. Tentang demokrasi ini, warga negara boleh ikut di dalam mengambil bagian, entah itu secara langsung atau dalam sebuah bentuk perwakilan dalam hal pelaksanaan perumusan, pengembangan dan juga proses menyusun hukum.

Demokrasi banyak dipakai suatu negara dengan beragam macamnya, macam-macam demokrasi dapat dikelompokkan dalam beberapa pembagian antara lain sebagai berikut:

a. Demokrasi berdasarkan penyaluran kehendak rakyat

- Demokrasi Langsung "Direct Democracy"

Demokrasi langsung yaitu demokrasi yang secara langsung dalam melibatkan rakyat untuk pengambilan keputusan terhadap suatu negara. Demokrasi langsung, rakyat secara langsung berpartisipasi dalam pemilihan umum dan menyampaikan kehendaknya.

- Demokrasi Tidak Langsung "Indirect Democracy” 
Demokrasi tidak langsung sdalah demokrasi yang tidak secara langsung melibatkan seluruh rakyat suatu negara dalam pengambilan keputusan. Demokrasi tidak langsung, rakyat menggunakan wakil-wakil yang telah dipercaya untuk menyampaikan aspirtasi dan kehendaknya. Yang sehingga dalam demokrasi tidak langsung wakil rakyat terlibat secara langsung dengan menjadi perantara seluruh rakyat.

b. Demokrasi berdasarkan fokus perhatiannya

- Demokrasi Formal, ialah demokrasi yang berfokus dari bidang politik tanpa mengurangi kesenjangan ekonomi.

- Demokrasi Material, ialah demokrasi yang berfokus di bidang ekonomi tanpa mengurangi kesenjangan politik.

- Demokrasi Gabungan, ialah demokrasi yang berfokus sama besar baik di bidang politik dan ekonomi.

c. Demokrasi berdasarkan prinsip ideologi

- Demokrasi Liberal

Demokrasi liberal yaitu demokrasi yang didasarkan dari hak individu suatu warga negara.

Demokrasi liberal dimana setiap individu dapat mendominasi dalam demokrasi ini. Pemerintah tidak akan banyak ikut campur dalam kehidupan masyarakat dimana pemerintah memiliki kekuasaan terbatas.

- Demokrasi Komunis

Demokrasi komunis ialah demokrasi yang berdasarkan dari hak pemerintah di negaranya dimana pemerintah mendominasi atau kekuasaan tertinggi dipegang oleh penguasa atau pemerintah. Demokrasi komunis tidak dibatasi dan bersifat totaliter yang membuat hak setiap individu tidak ada pengaruhnya pada pemerintah.

- Demokrasi Pancasila

Demokrasi Pancasila adalah demokrasi yang didasarkan dari ideologi Indonesia, yaitu Pancasila berdasarkan dari tata sosial dan budaya bangsa Indonesia, demokrasi pancasila merupakan yang dianut Indonesia.

Demokrasi yang diterapkan di Indonesia adalah demokrasi Pancasila. Winarno (2007: 102) mengungkapkan bahwa Pancasila adalah ideologi nasional, yaitu seperangkat nilai yang dianggap baik, sesuai, adil, dan menguntungkan bangsa. Pancasila menjadi cita-cita masyarakat, sehingga 
dijadikan pedoman dalam membuat keputusan. Adapun ciri-ciri demokrasi Pancasila adalah sebagai berikut:

- Demokrasi Pancasila bersifat kekeluargaan dan gotong royong yang bernafas Ketuhanan Yang Maha Esa

- Menghargai hak hak asasi manusia serta menjamin hak hak minoritas

- Pengambilan keputusan dalam demokrasi pancasila sedapat mungkin didasarkan atas musyawarah untuk mufakat

- Demokrasi pancasila harus bersendi atas hukum

Selain ciri-ciri, demokrasi Pancasila mempunyai prinsip-prinsip, diantaranya ialah :

a. Adanya perlindungan HAM

b. Keputusan diambil berdasarkan musyawarah

c. Adanya badan peradilan independen yang bebas dari intervensi pemerintah atau kekuasaan lainnya

d. Adanya partai politik dan organisasi sosial politik sebagai media untuk menyalurkan aspirasi rakyat.

e. Rakyat merupakan pemegang kedaulatan dan dilaksanakan berdasarkan UUD 1945.

f. Berperan sebagai pelaksana dalam PEMILU

g. Kebebasan individu harus bertanggungjawab secara moral kepada Tuhan Yang Maha Esa, diri sendiri, masyarakat, dan negara

h. Penyelenggaraan pemerintah berdasarkan hukum, sistem konstitusi, dimana kekuasaan tertinggi berada di tangan rakyat.

\section{4) Masa kini}

Artian masa kini yang dimaksud dalam penelitian ini adalah masa digital yang berarti bahwa gaya hidup manusia tergantung pada internet di masa sekarang atau hal ini juga bisa disebut sebagai globalisasi yang memudahkan kita dalam mengakses informasi yang seolah-olah dunia tidak ada batasnya.

Era digital bisa juga disebut dengan globalisasi. Globalisasi adalah proses integrasi internasional yang terjadi karena pertukaran pandangan dunia, produk, pemikiran, dan aspekaspek kebudayaan lainnya yang banyak disebabkan oleh kemajuan infrastruktur telekomunikasi, transportasi dan internet. Era digital merupakan suatu masa dimana sebagian besar masyaraat pada masa ini menggunakan sistem digital dalam kehidupan sehari-hari. Sistem digital ini terbukti 
lebih mutakhir dari sistem yang berkembang sebelumnya, yaitu sistem analog. Sistem kerja analog berbeda dengan sistem digital. Sistem analog menghasilkan sinyal tiruan dari suara atau sinyal asli dari alam, jadi kualitas sinyal tiruan yang didapat lebih sedikit daripada yang disebabkan oleh faktor degradasi sinyal dan suara latar yang diputar. Sedangkan sistem digital dapat menghilangkan faktor pengganggu saat menstransmisikan sinyal asli dengan cara pengkodean (merubah sinyal menjadi bit) dan membuat sampel gelombang suara dan menerjemahkannya dalam interval yang diubah. Jadi hasilnya lebih jernih, akurat dan tidak tertunda sinyal (Carlin, 2010 : 229-230).

\section{5) Pelaksanaan demokrasi di media sosial dalam pemilu 2019}

Pemilihan presiden Indonesia 2019 berada dalam paradoks janggal. Di satu sisi, platform kebijakan kedua kandidat presiden nyaris tak menunjukkan perbedaan yang signifikan. Alih-alih mengkritik Presiden Joko Widodo, kampanye kandidat oposisi Prabowo Subianto relatif pasif dan malu-malu. Sebagian besar orang Indonesia menganggap debat pilpres di televisi membosankan. Wartawan lokal dan asing pun mengklaim tak ada hal menarik selama kampanye berlangsung. Kandidat presiden dan wakil presiden tidak menawarkan perdebatan yang jelas terkait arah masa depan negara ini.

Seorang dosen mengatakan wacana politik saat ini "buruk untuk Indonesia dan tidak dapat dikendalikan", ketika mahasiswa "tidak boleh sepakat untuk tidak bersepakat". Dalam sesi kuliah saya, seorang mahasiswa meminta saran tentang bagaimana Indonesia bisa "damai" di tengah situasi politik yang keruh. Namun, apakah yang sebenarnya mendorong perbedaan kontras antara kampanye politik yang relatif menjemukan dan perasaan banyak orang yang resah terkait itu? Salah satu cara untuk menjawab pertanyaan ini adalah mengamati bagaimana kehidupan online mengubah realitas offline. Barangkali Indonesia tidak mengalami kampanye politik yang memecah belah, atau polarisasi, melainkan diskursus media sosial membuat masyarakat Indonesia merasakan potensi polarisasi lebih besar dibandingkan yang sebenarnya dan politikus terus-terusan mengobarkan persepsi itu yang bisa saja menyebabkan terpecah belahnya perdamaian.

Bercermin pada beberapa kasus luar biasa, para pakar di Indonesia telah memperingatkan bahwa media sosial mudah memicu konflik karena tingkat literasi yang rendah. Menurut akademisi Indonesia Adi Prayitno, "Banyak orang Indonesia masih irasional dan cenderung emosional ketika berhadapan dengan pandangan politik yang berbeda," yang lantas membuat 
mereka berpikir politik adalah "jalan menuju surga atau pertarungan antara yang baik dan yang jahat". Lihat saja percakapan media sosial di Indonesia sehari-hari saat pendukung Jokowi dipanggil "cebong" dan pendukung Prabowo dijuluki "kampret". Polarisasi media sosial di Indonesia akhirnya sering dibandingkan dengan apa yang terjadi di Amerika Serikat. Orang asing biasanya langsung menilai kebanyakan orang Indonesia tak menyadari apa yang terjadi di dunia internasional. Namun, pemilu Amerika adalah pengecualian, setidaknya di kalangan elite. Dalam pidatonya baru-baru ini, Agus Harimurti Yudhoyono (AHY) mengatakan perpecahan politik disebabkan oleh maraknya berita bohong dan hoax di media sosial. "Jika situasi ini berlanjut," katanya, "itu akan mengakhiri sistem multipartai dan akan membawa negara ini ke sistem dua partai seperti di Amerika Serikat." AHY menambahkan sistem dua partai tidak cocok dengan latar belakang historis dan kemajemukan bangsa Indonesia. Wakil Kepala Kepolisian Nasional Ari Dono Sukmanto mengamini pendapat AHY, "[Pengaruh yang salah dari informasi yang salah] terjadi di Pilpres [2016] di Amerika Serikat. Mungkin ini juga bisa terjadi pada kita". Dalam wawancara pribadi, salah seorang juru kampanye di kubu Jokowi bercerita kepada saya tentang bagaimana pemilihan AS memberikan pelajaran penting untuk merespons "kampanye "hitam": "Michele Obama mengatakan, 'When they go low, we go high' (ketika kubu pembuat hoax memakai taktik rendahan, kita harus bertahan dengan prinsip-prinsip moral kita). Nyatanya, cara itu tak berhasil. Trump menang.

Jadi, dalam kasus Indonesia, 'When they go low, we go lower." Polarisasi Apa? Terlepas dari semua kekhawatiran tentang perpecahan, disinformasi, dan berita bohong, temuan survei belum berubah. Jokowi masih memimpin dengan elektabilitas sekitar 57 persen, melampaui elektabilitas Prabowo pada angka 32 persen. Artinya, apa pun yang telah diproduksi untuk meramaikan dunia maya atau media sosial, sejauh ini tidak mengubah temuan survei secara signifikan. Alih-alih menciptakan kondisi "darurat hoax", sebagian besar orang yang sibuk memerangi satu sama lain adalah pasukan siber dari kedua kubu. Sementara itu, anak muda Indonesia semakin menghindari diskursus politik yang kian meruncing, terutama di Twitter dan Facebook, sehingga beralih ke platform apolitis.

\section{METODE PENELITIAN}

Pendekatan penelitian yang digunakan yaitu pendekatan kualitatif. Moleong (2005:6) mendefinisikan penelitian kualitatif adalah penelitian yang bermaksud untuk memahami fenomena tentang apa yang dialami oleh subjek penelitian misalnya perilaku, persepsi, motivasi, 
tindakan, dan lain-lain secara holistic, dan dengan cara deskripsi dalam bentuk kata-kata dan bahasa, pada suatu konteks khusus yang alamiah dan dengan memanfaatkan berbagai metode alamiah. Penelitian ini dilaksanakan di lingkungan Universitas Tidar Magelang Jalan Kapten Suparman No. 39, Potrobangsan, Magelang Utara 56116. Lokasi ini dipilih peneliti agar dapat mengukur pengetahuan mahasiswa sebagai kaum akademisi mengenai peran media sosial dalam demokrasi saat ini, khususnya mahasiswa diluar Fakultas Ilmu Sosial dan Ilmu Politik. Informan yang dituju adalah mahasiswa non-FISIP di Universitas Tidar, karena dalam penelitian ini memfokuskan pada sudut pandang mereka yang tidak mendalami ilmu politik atau kenegaraan. Mengingat keterbatasan kemampuan dari peneliti, terkait dengan waktu dan tenaga, maka dilakukan pengambilan sampel. Teknik pengambilan sampel yang dilakukan adalah nonprobabilitas dengan teknik kuota sampling.

Peneliti menggunakan 2 jenis sumber data, yaitu data primer dan data sekunder. Data primer diperoleh dari hasil wawancara para informan. Sedangkan data sekunder berupa data tambahan yang mendukung data primer dapat berasal dari teori-teori, jurnal, buku dan internet yang relevan dengan pembahasan penelitian ini. Penelitian ini menggunakan teknik pengumpulan data wawancara mendalam dengan informan dan pengamatan terlebih dahulu. Instrumen yang digunakan pada penelitian ini yaitu seperti pedoman survei, pedoman wawancara dan alat tulis sesuai dengan metode pengumpulan data yang digunakan.

\section{HASIL DAN PEMBAHASAN}

Setelah kita melihat hasil penelitian yang diperoleh dari teknik pengumpulan data dengan wawancara, hampir seluruh responden mengetahui istilah demokrasi secara umum dan penggunaan media sosial yang sering di kalangan mereka. Dalam era globalisasi ini, media sosial sangat diperlukan di setiap aktivitas manusia, tak terkecuali dalam lingkup dunia politik untuk kepentingan demokrasi. Ini karena media sosial dapat dijadikan ruang publik untuk menyampaikan aspirasi masyarakat terkait pendapat, saran maupun kritik terhadap jalannya sistem demokrasi. Sebagian dari responden ini, mengakui ikut berpartisipasi dalam sosial media terkait demokrasi, seperti berkomentar pada kolom komentar. Namun dari mereka berpendapat bahwa lebih suka berpartisipasi secara langsung atau spontanitas tanpa terlibat di sosial media. Menurut Isbandi (2007: 27), partisipasi masyarakat adalah keikutsertaan masyarakat baik dalam proses mengidentifikasi permasalahan, maupun potensi yang ada di sekitar masyarakat. Meliputi proses memilih dan mengambil sebuah keputusan, baik alternatif solusi untuk menangani 
masalah, maupun proses pelaksanaan mengatasi masalah, serta keterlibatan dalam hal mengevaluasi perubahan yang terjadi. Masyarakat dalam berpartisipasi merupakan suatu perwujudan dari demokrasi. Demokrasi sebagai landasan bagi hadirnya partisipasi masyarakat untuk turut serta dalam menjalankan pemerintahan yang baik, terutama dalam fungsi pengawasan dan pembahasan suatu peraturan. Dan dengan adanya penggunaan media sosial, pertumbuhan partisipasi masyarakat meningkat walaupun partisipasi tidak secara langsung.

Penggunaan media sosial pastinya memberikan kontribusi, baik secara positif maupun negatif terhadap pelaksanaan demokrasi. Dalam pembahasan ini, rata-rata dari responden berpendapat bahwa sesuai dengan pandangan dan penggunaan dari diri sendiri terhadap informasi yang diberikan. Dalam kontribusi negatif, yang lekat pada saat ini adalah informasi hoax. Hoax (berita bohong) merupakan informasi yang sesungguhnya tidak benar tetapi dibuat seolah-olah benar. Oknum pembuat konten hoax umumnya dilatarbelakangi beberapa motif, mulai dari ekonomi, politik dan tidak sedikit juga yang berlandaskan pada eksistensi di dunia maya. Bentuknya beragam mulai dari berita bohong, ujaran kebencian berdasarkan SARA, provokasi, pemutarbalikkan fakta, terorisme dan konten-konten negatif lainnya. Kini, banyak muncul hoax di sosial media, khususnya topik tentang politik. Penyebaran berita atau informasi hoax, menurut Koordinator Mayarakat Anti Fitnah Indonesia (Mafindo) Surabaya, Adven Sarbani, menjadi isu yang berbahaya dalam hidup berbangsa dan bermasyarakat. Isu suku, agama, ras, dan antar golongan (SARA) hingga ujaran kebencian menjadi materi berbahaya dalam penyebaran berita hoax, terutama memasuki tahun politik menjelang Pemilu 2019. Apalah arti berita palsu bila tak ada yang memperhatikan. Seburuk apa pun berita hoax, kalau tidak ada peminatnya, akan mati dengan sendirinya. Sebaliknya, seremeh apa pun hoax, apabila terus dibagikan, dipublikasikan, dan diulang terus-menerus, akan tampak sebagai kebenaran. Sebagai warga negara yang baik, harus bijak dalam membedakan informasi yang ada di media sosial tersebut tidak berujung hoax. Agar dapat memberikan kontribusi yang positif maka setiap masyarakat harus menyaring informasi yang didapat atau tidak gampang terbujuk kamuflase berita-berita palsu yang menyesatkan.

Terkait penyalahgunaan media sosial, hampir semua responden mengatakan bahwa penyalahgunaan media akan dapat merubah prinsip-prinsip demokrasi Indonesia. Karena informasi yang tidak benar dan mudahnya kepercayaan masyarakat dapat merubah kepribadian dari masyarakat itu sendiri secara perlahan. Maraknya penyebaran hoax di tengah masyarakat kini 
telah mengancam jalinan persaudaraan dalam kehidupan berbangsa dan bernegara di ruang-ruang sosial. Dapat dilihat secara nyata, bahwa hoax bisa memunculkan adanya permusuhan dan perpecahan pada sekelompok masyarakat. Itu artinya bahwa hoax juga akan berpengaruh pada runtuhnya persatuan dan keutuhan bangsa. Dan ini juga telah menyimpang nilai-nilai yang ada pada Pancasila sebagai landasan demokrasi bangsa Indonesia. Untuk itu perlu adanya kebijakan atau aturan berkaitan dengan penggunaan media sosial, seperti UU ITE. Agar penggunaan media sosial dalam pelaksanaan demokrasi khusunya dapat diarahkan dan dibatasi sesuai nilai kemanusiaan, persatuan, keadilan, dan kepentingan bersama.

\section{E. SIMPULAN}

Berdasarkan hasil penelitian yang dijabarkan, maka dapat ditarik simpulan :

Pertama, media sosial memiliki peran yang penting dalam pelaksanaan demokrasi di Indonesia. Media sosial dapat membuat masyarakat semakin terbuka akan kinerja pemerintah dan mampu menyampaikan pendapatnya melalui media sosial yang semakin mudah diakses oleh seluruh kalangan masyarakat.

Kedua, media sosial mempunyai kontribusi yang positif dan negatif. Dalam kontribusi negatif yaitu berkaitan dengan informasi hoax. Agar dapat memberikan kontribusi yang positif maka setiap masyarakat harus menyaring informasi yang didapat atau tidak gampang terbujuk kamuflase berita-berita palsu yang menyesatkan.

Ketiga, penyalahgunaan media sosial dapat merubah prinsip-prinsip demokrasi Indonesia. Karena informasi yang tidak benar dan mudahnya kepercayaan masyarakat dapat merubah kepribadian dari masyarakat itu sendiri secara perlahan.

Di era globalisasi ini, peran media sosial dalam masyarakat diharapkan dapat memberikan dampak yang positif dalam masyarakat. Dan juga dengan media sosial masyarakat mampu melaksanakan demokrasi yang baik dan sesuai dengan UUD 1945. Penyimpangan di media sosial pada zaman ini tentu dapat mempengaruhi jalannya demokrasi Indonesia. Maka dari itu, sebagai pengguna harus kritis dalam mencari informasi, tidak mudah percaya, dicari faktanya dulu serta memberi teguran kepada orang yang menyebarkan berita hoax. Salah satu upaya pemerintah dalam mengatasi masalah tersebut yaitu membuat kebijakan atau aturan tentang penyalahgunaan media sosial, seperti UU ITE. Memerangi hoax menuntut keterlibatan semua lapisan masyarakat untuk bahu-membahu bersama pemerintah membangun kesadaran bersama sehingga dapat memanfaatkan media sosial secara bertanggung jawab dengan konten-konten positif. 


\section{F. DAFTAR PUSTAKA}

Misbahruddin, A. (2016). "Pemanfaatan Teknologi Informasi Dan Komunikasi (TIK) Oleh Rumah Tangga Untuk Kehidupan Sehari-Hari”. Jurnal Penelitian Pers dan Komunikasi Pembangunan. Vol 18(1) : 1-16.

Munawaroh, Isniatun. "Pemanfaatan Teknologi Informasi dan Komunikasi Untuk Menumbuhkan Kreativitas dan Kemandirian Belajar". Universitas Negeri Yogyakarta (2010).

Sulianta, Feri. (2015). Keajaiban Sosial Media. Jakarta: Elex Media Komputindo.

Winarno, Paradigma Baru Pendidikan Kewarganegaraan Panduan Kuliah di Perguruan Tinggi. Ed. III. Cet. III. (Jakarta: Bumi Aksara, , Paradigma Baru Pendidikan Kewarganegaraan. Cet. I. Jakarta: Bumi Aksara, untuk Perguruan Tinggi

Dwi, Erika. (2011). “Komunikasi dan Media Sosial”. Jurnal The Messenger. Vol 3(1) : 69-75. Arfianto Purbolaksono. (2018). Media Sosial, Pilkada Serentak dan Pemilu 2019.[Online]. Tersedia : https://www.theindonesianinstitute.com/media-sosial-pilkada-serentak-dan-pemilu2019/ [03 Juni 2019].

Fakhri, Azwanil. 2016. "Merawat Demokrasi Dalam Bingkai Kebebasan Pers". https://www.academia.edu/34852963/Demokrasi_dalam_Media_Massa.docx [03 Juni 2019].

Ameidyo Daud. (2019). Hasil Survei: Media Sosial Mempengaruhi Pilihan saat Pemilu. [Online]. Tersedia : https://katadata.co.id/berita/2019/04/05/hasil-survei-media-sosialmempengaruhi-pilihan-saat-pemilu[03 Juni 2019].

Fitria Chusna. (2018). Peserta Pemilu Diizinkan Kampanye Lewat Media Sosial, tapi Harus Hati-Hati. Tersedia : https://nasional.kompas.com/read/2018/08/30/19462201/peserta-pemiludiizinkan-kampanye-lewat-sosial-media-tapi-harus-hati-hati[03 Juni 2019].

Mutiara Auliya. (2018). Mudahnya Hidup di Era Digital. [Online]. Tersedia : https://www.domainesia.com/berita/era-digital-adalah/[03 Juni 2019].

Levriana Yustriani. (2019). Pemilu 2019: Polarisasi Medsos atau Ideologis?. [Online]. Tersedia : https://tirto.id/pemilu-2019-polarisasi-medsos-atau-ideologis-dkUq[03 Juni 2019]. 